\title{
Analyses of Airborne Contamination with Bacteria, Endotoxins and Dust in Livestock Barns and Poultry Houses
}

\author{
B. BAKUTIS, E. MONSTVILIENE, G. JANUSKEVICIENE \\ Department of Food Safety and Animal Hygiene, Lithuanian Veterinary Academy, \\ Kaunas, Lithuania
}

Received June 23, 2003

Accepted June 17, 2004

\begin{abstract}
B. Bakutis, E. Monstviliene, G. Januskeviciene: Analyses of Airborne Contamination with Bacteria, Endotoxins and Dust in Livestock Barns and Poultry Houses. Acta Vet. Brno 2004, 73: 283-289.

In the air of livestock houses different amounts of microorganisms are present along with dust. The aim of this study was to compare results of quantitative analyses of airborne bacteria, endotoxins and dust in livestock and poultry houses. In insulated cowsheds for dairy cows the average amount of microorganisms and gram-negative bacteria were higher than in uninsulated cowsheds $(p<0.01)$. Average amounts of microorganisms and gram-negative bacteria in pig and poultry houses were higher than in insulated and uninsulated cowsheds $(p<0.01)$, and the air of pig and poultry houses was more contaminated with endotoxins than that of insulated and uninsulated cowsheds $(p<0.01)$. In insulated cowsheds the concentration of dust was higher than in uninsulated cowsheds $(p<0.01)$. In pig and poultry houses the concentration of dust was higher than in insulated and uninsulated cowsheds $(p<0.01)$. We detected a close connection among the amount of dust and airborne bacteria and their endotoxins in air of livestock and poultry houses. There is a need for further reducing the emission of environmentally harmful substances. Precise data of this type are of importance for licensing new animal farms as well as residential areas in the farming environment.
\end{abstract}

Airborne bacteria, gram-negative bacteria, insulated, cowsheds, pig houses, poultry houses

Dust and microorganisms with different admixtures are abundant in the air of livestock houses (Zucker et al. 2000a), and the amount of endotoxins in the samples of air is related to intensive microbial pollution of the environment. During the development of gramnegative bacteria as well as due to their autolysis or phagocyte activity endotoxins spread in the environment and accumulate in dust, on the surface of buildings as well as in the air (Afanasyeva 1997). The term "endotoxin" found in literature means the definition of lipopolysaccharide complex, related to the structure of membrane of gram-negative bacteria. So, endotoxins are a part of external membrane of E. coli, Salmonella, Shigella, Pseudomonas, Neisseria, Haemophilus and other gram-negative bacteria (Riet schel et al. 1993; Heederik et al. 1997; Hartung et al. 1999; Zucker et al. 2000a). Definition of lipopolysaccharides indicates that they are stable, water-soluble molecules, made of lipid A, $\mathrm{O}$-specific chains and polysaccharide nucleus. Lipid A is a chemical compound, which consists of glucosamine disaccharide, $\mathrm{PO}_{4}$ group, acylic chain and inner core with $\mathrm{KDO}$ (2keto-3-deoxysioctanoic acid) (Sitnikov et al. 1997). Lipopolysaccharides of gramnegative bacteria determine biological features of endotoxins, toxicity is determined by lipidic part of LPS, and imunogenetics is conditioned by polysaccharide components (Rietschel et al. 1993).

Quantitative analyses of endotoxins are performed in animal housings in many countries in Europe, in the USA, and Canada. Concentrations of endotoxins transmitted in air differ not only in different environments, but also in the same environment depending on

\footnotetext{
Address for correspondence:

B. Bakutis

Department of Veterinary Hygiene and Food Sanitation

Lithuanian Veterinary Academy, Tilžès 18

LT-3022 Kaunas, Lithuania
}

Phone: +37037363208

E-mail: zoohig@lva.lt

http://www.vfu.cz/acta-vet/actavet.htm 
conditions and work peculiarities, type of livestock, way of animal keeping and system of farm management (Müller et al. 1987; Wijnand 1997; Zucker et al. 2000b).

Inhalation of organic dust contaminated by endotoxins may cause symptoms of bronchial diseases and inflammatory response (Hartung et al. 1999). Epidemiological studies in livestock indicate that due to long-term influence of endotoxins, chronic bronchitis and deficiency of lung function might develop. There is a great probability that both acute and chronic effects are caused by inflammatory responses in lungs where alveolar macrophages play the main role (Rylander 1987). The research carried out in experimental animals proved that injections of lipopolysaccharides cause non-specific pathologic-physiological reactions of wide spectrum, such as fever, leucocytosis, coagulation, necrosis of neoplasm, hypotension or shock, and infections of big doses of endotoxin end in death (Af a n a s ye va 1997). According to Zucker et al. (2000b), endotoxins reach the humoral and cellular systems. Carcinogenic, mutagenic and reproductive effects of endotoxins have also been described (Heederik et al. 1997). Epidemiological and experimental studies gave enough data that enabled to identify criteria of professional influence related to people's health (Wijnand 1997), very little is known about the effect of endotoxins on housed animals (Zucker and Müller 2000).

The purpose of this study was to compare quantitative analyses of airborne bacteria, endotoxins and dust in livestock barns and poultry houses in Lithuania during the winter (November - March).

\section{Materials and Methods}

The research was carried out in November-March 2001-2002 in insulated and uninsulated cowsheds for dairy cows, in pig houses and poultry houses. The dairy cows were kept in the cold barns equipped with boxes and in the insulated barns, where cows were kept tied. Temperature was $4.5^{\circ} \mathrm{C}$ on average and relative humidity was $86.1 \%$ on average in the cold box barns. In the insulated barns temperature was $11.3^{\circ} \mathrm{C}$ on average and relative humidity was $74.5 \%$ on average. Temperature was $16.3{ }^{\circ} \mathrm{C}$ on average and relative humidity was $71.9 \%$ on average in the pig houses, and $17.1{ }^{\circ} \mathrm{C}$ on average and relative humidity was $65.8 \%$ on average in the poultry houses.

To perform quantitative analyses of microorganisms in the air, the air samples were taken from three places in each livestock house according to the longitudinal axis of the building using the Krotov method. Into the Krotov sampler the air was ventilated through a narrow slot at an airflow rate of 20-40 1/min for 5 minutes. Microorganisms were collected on the standard plate count agar (Oxoid, APHA, CM 463) in Petri dishes. The dishes were incubated at $37^{\circ} \mathrm{C}$ for 24 hours. The grown colonies were counted and the average amount of microorganisms was calculated for the $1 \mathrm{~m}^{3}$ air (Tarvydas 1992). To perform the quantitative analyses of gram-negative bacteria, characteristic colonies from the surface of the agar were counted and average amount of the colonies was determined. In order to determine gram-negative bacteria, the $\mathrm{KOH}$ test was applied: the culture of bacteria grown for twenty-four hours was added to a drop of $3 \% \mathrm{KOH}$ solution and well mixed. After 1-2 min due to lysis of gram-negative bacteria consistence the drop becomes slimy (Sitnikov et al. 1997).

Samples of airborne endotoxins were collected in $50 \mathrm{ml}$ of pyrogen free water. A glass impinger and air pump, operating for $20 \mathrm{~min}$. at an airflow rate of $12.5 \mathrm{l} / \mathrm{min}$ were used. The classical test Limulus Amebocyths Lisat (LAL) was applied to test the concentrations of bacterial endotoxin in aerosol fractions in acordance with manufactureres instructions (Pearson et al, 1982). The concentrations of bacterial endotoxins were calculated in the air of the livestock and poultry houses using Test LAL - PYROGENT ${ }^{\circledR}$ (B. I. Bioproducts, Germany). The concentrations of endotoxins, obtained from the sample fluids, were converted from EU/ml ${ }^{-1}$ to $\mathrm{EU} / \mathrm{m}^{-3}$, using the air flow rate and the sampling time. The sample analyses were performed in the "Sanitas" laboratory PLC (Quality System. Permit No. 1. 410-C05-PRM-03-2001. Registration No. PRM/05-118). Concentrations of airborne endotoxins in all livestock houses were determined during feeding and removal of manure because at these times the concentrations of endotoxins could be increased.

The gravimetric method using the non-ash paper filter of 6.5 diameter, AFA type was applied to determine the amount of the dust in livestock houses ( $\mathrm{mg} / \mathrm{m}^{3}$ air). The cassette of Patron with filter was connected to the air pump and the air was pumped for $20 \mathrm{~min}$. After that the filter was weighed on the analytic scale with precision of 0.05 $\mathrm{mg}$. The pumped air volume was recounted under normal conditions, i.e. $0{ }^{\circ} \mathrm{C}$ temperature and $760 \mathrm{~mm} \mathrm{Hg}$ atmospheric pressure (Tarvydas 1992).

Statistical analysis. The results were processed using Prism 2.01 programme. Both ANOVA (analysis of variance) and the non-parametric Wilcoxon sum-rank test were used to reveal differences among groups of samples. All values were expressed as mean $\pm \mathrm{SE}$ and the significance of the correlation between groups was tested. A $p$-value of less than 0.01 was considered significant. 


\section{Results and Discussion}

We investigated microbiological conditions of air in different livestock and poultry houses and identified average amount of viable airborne bacteria and amount of viable airborne gram-negative bacteria in $1 \mathrm{~m}^{3}$ air (Table 1).

Table 1

Average amount of airborne bacteria and airborne gram-negative bacteria $\times 10^{3} \mathrm{cfu} / \mathrm{m}^{3}$ air

\begin{tabular}{|l|l|l|l|l|l|l|l|l|}
\hline $\begin{array}{l}\text { Period, } \\
\text { month }\end{array}$ & \multicolumn{2}{l}{$\begin{array}{l}\text { Insulated } \\
\text { cowsheds }\end{array}$} & \multicolumn{2}{l|}{$\begin{array}{l}\text { Uninsulated } \\
\text { cowsheds }\end{array}$} & \multicolumn{2}{l|}{ Pig houses } \\
\hline & $\begin{array}{l}\text { Average } \\
\text { amount } \\
\text { of bacteria }\end{array}$ & $\begin{array}{l}\text { Gram- } \\
\text { negative } \\
\text { bacteria }\end{array}$ & $\begin{array}{l}\text { Average } \\
\text { amount } \\
\text { of bacteria }\end{array}$ & $\begin{array}{l}\text { Gram- } \\
\text { negative } \\
\text { bacteria }\end{array}$ & $\begin{array}{l}\text { Average } \\
\text { amount } \\
\text { of bacteria }\end{array}$ & $\begin{array}{l}\text { Gram- } \\
\text { negative } \\
\text { bacteria }\end{array}$ & $\begin{array}{l}\text { Average } \\
\text { amount } \\
\text { of bacteria }\end{array}$ & $\begin{array}{l}\text { Gram- } \\
\text { negative } \\
\text { bacteria }\end{array}$ \\
& 70.76 & 6.56 & 61.48 & 5.44 & 156.80 & 4.26 & 714.70 & 13.93 \\
\hline 11 & \pm 3.69 & \pm 0.42 & \pm 5.20 & \pm 0.70 & \pm 34.34 & \pm 2.44 & \pm 11.53 & \pm 1.44 \\
\hline 12 & 91.74 & 7.69 & 7.05 & 5.28 & 171.20 & 9.45 & 334.10 & 12.73 \\
& \pm 4.27 & \pm 1.21 & \pm 0.71 & \pm 0.48 & \pm 4.08 & \pm 0.58 & \pm 4.56 & \pm 3.60 \\
\hline 01 & 69.80 & 6.72 & 25.62 & 5.12 & 230.80 & 15.21 & 394.80 & 10.33 \\
& \pm 6.40 & \pm 0.73 & \pm 4.31 & \pm 1.16 & \pm 20.89 & \pm 1.67 & \pm 72.05 & \pm 2.16 \\
\hline 02 & 58.92 & 9.60 & 36.34 & 4.16 & 248.60 & 7.85 & 777.60 & 13.45 \\
& \pm 5.16 & \pm 0.28 & \pm 10.45 & \pm 0.42 & \pm 20.41 & \pm 0.85 & \pm 20.61 & \pm 0.48 \\
\hline 03 & 95.42 & 8.17 & 34.10 & 4.80 & 119.50 & 9.13 & 109.20 & 11.29 \\
& \pm 1.20 & \pm 1.39 & \pm 3.05 & \pm 0.28 & \pm 94.19 & \pm 0.48 & \pm 81.94 & \pm 2.16 \\
\hline Average & 77.33 & 7.75 & 32.92 & 4.96 & 185.88 & 9.18 & 466.08 & 12.35 \\
& \pm 4.14 & \pm 0.81 & \pm 4.74 & \pm 0.61 & \pm 34.78 & \pm 1.20 & \pm 38.14 & \pm 1.97 \\
\hline
\end{tabular}

The results of bacteriological tests indicate that the concentrations of airborne bacteria in insulated and uninsulated cowsheds for dairy cows were much smaller than in pig houses and poultry houses. Comparative analysis of microbiological contamination between the separate cowsheds showed that average amount of microorganisms in insulated cowsheds was approximately 2.3 times higher than in uninsulated cowsheds $(p<0.01)$. Comparison of gram-negative bacteria average amount indicated that in insulated cowsheds amount of bacteria was 1.6 times higher than in uninsulated cowsheds $(p<0.001)$. Gram-negative bacteria made in average $10.0 \%$, from the average amount of bacteria in insulated cowsheds and $15.0 \%$ in uninsulated cowsheds. In pig houses and poultry houses the average amount of microorganisms was 5.6 and even 14.1 times $(p<0.001)$ higher than in uninsulated cowsheds and $2.3(p<0.001)$ and 6.0 times $(p<0.01)$ higher than in insulated cowsheds. Gram-negative bacteria made approximately $4.9 \%$ of the average amount of bacteria in pig houses, and $2.6 \%$ in poultry houses. As evident, the highest microbial contamination was observed in poultry houses, where both the average amount of microbes, and the amount of gram-negative bacteria correspondingly were 2.5 and 1.3 times higher than in pig houses. Nevertheless, the differences were not statistically significant. The amount of viable gramnegative bacteria in the air of pig houses was approximately 1.2 times higher than in insulated cowsheds and 1.8 times higher $(p<0.01)$ than in uninsulated cowsheds. In poultry houses the average amount of gram-negative bacteria was $1.6(p<0.001)$ and $1.9(p<0.001)$ times higher than in insulated and uninsulated cowsheds.

The results indicated that concentrations of airborne endotoxins in livestock houses were different and depended on the animal species kept in farm as well as on the sanitary state of the farm. Concentrations of bacterial endotoxins (in endotoxin units and ng) that were determined in aerosol fractions of different livestock and poultry houses in $1 \mathrm{~m}^{3}$ air are presented in Tables 2 and 3. Average amount of airborne endotoxins in insulated cowsheds 
varied from 100 to $800 \mathrm{EU} / \mathrm{m}^{3}$. This corresponds to $10-80 \mathrm{ng} / \mathrm{m}^{3}$. Meanwhile, in cowsheds the amounts of endotoxins ranged in the limits of 50-200 EU/m3 $\left(5-20 \mathrm{ng} / \mathrm{m}^{3}\right)$, and the values were 3.2 times higher than in insulated cowsheds. The determined average concentrations of endotoxins in the insulated cowshed were $290 \mathrm{EU} / \mathrm{m}^{3}$ higher than in uninsulated cowshed or in the air aerosol samples $(p<0.01)$.

Table 2

Endotoxins concentrations in the insulated and uninsulated cowsheds

\begin{tabular}{|l|l|l|l|l|}
\hline \multirow{2}{*}{ Year, month } & \multicolumn{3}{|l|}{ Insulated cowsheds } & \multicolumn{2}{l|}{ Uninsulated cowsheds } \\
\cline { 2 - 5 } & \multicolumn{2}{|l|}{ Concentration of endotoxins } & $\mathrm{EU} / \mathrm{m}^{3}$ \\
\cline { 2 - 5 } & $\mathrm{EU} / \mathrm{m}^{3}$ & $\mathrm{ng} / \mathrm{m}^{3}$ & 100 & 10,0 \\
\hline 2001,11 & 400 & 40 & 200 & 20,0 \\
\hline 2001,12 & 400 & 40 & 200 & 20,0 \\
\hline 2002,01 & 400 & 40 & 100 & 10,0 \\
\hline 2002,02 & 100 & 80 & 50 & 5,0 \\
\hline 2002,03 & 800 & $42.0 \pm 11.1$ & $130 \pm 30.0$ & $13.0 \pm 3.0$ \\
\hline Average & $420.0 \pm 111.4$ & & \\
\hline
\end{tabular}

Table 3

Concentrations of endotoxins in pig houses and poultry houses

\begin{tabular}{|l|l|l|l|l|}
\hline \multirow{2}{*}{ Year, month } & \multicolumn{3}{|l|}{ Pig houses } & \multicolumn{2}{l|}{ Poultry houses } \\
\cline { 2 - 5 } & \multicolumn{2}{|l|}{ Concentration of endotoxins } \\
\cline { 2 - 5 } & $\mathrm{EU} / \mathrm{m}^{3}$ & $\mathrm{ng} / \mathrm{m}^{3}$ & $\mathrm{EU} / \mathrm{m}^{3}$ & $\mathrm{ng} / \mathrm{m}^{3}$ \\
\hline 2001,11 & 800 & 80 & 12800 & 1280 \\
\hline 2001,12 & 800 & 80 & 1600 & 160 \\
\hline 2002,01 & 3200 & 320 & 3200 & 320 \\
\hline 2002,02 & 1600 & 160 & 3200 & 320 \\
\hline 2002,03 & 400 & 40 & 800 & 80 \\
\hline Average & $1360 \pm 499.6$ & $136.0 \pm 50.0$ & $4240 \pm 2204$ & $400.0 \pm 228.7$ \\
\hline
\end{tabular}

Comparing different livestock and poultry houses it was observed that in pig houses and poultry houses the air contamination with endotoxins was higher than in cowsheds (Table $3)$. In pig houses the levels of endotoxins varied in the limits of 400-3200 EU/m $3 \mathrm{~m}^{3}(40-320$ $\left.\mathrm{ng} / \mathrm{m}^{3}\right)$. The average values of endotoxins in pig houses were 3.2 times higher than in insulated cowsheds and even 10.4 times higher $(p<0.01)$ than in uninsulated cowsheds. The air contamination with endotoxins in pig houses was approximately $940 \mathrm{EU} / \mathrm{m}^{3}$ higher than in the air of insulated cowsheds, and $1230 \mathrm{EU} / \mathrm{m}^{3}$ higher $(p<0.01)$ than in uninsulated cowsheds. The air contamination with endotoxins in pig houses was 3.1 times (or 2960 $\mathrm{EU} / \mathrm{m}^{3}$ ) smaller than in the air of poultry-houses.

Concentrations of endotoxins in air aerosol fractions from poultry houses varied from 800 to $12800 \mathrm{EU} / \mathrm{m}^{3}\left(80-1280 \mathrm{ng} / \mathrm{m}^{3}\right)$. The average concentrations of endotoxins in poultry houses were 10.0 times higher than in insulated cowsheds and even 33.2 times higher than in uninsulated cowsheds. This was approximately $3900 \mathrm{EU} / \mathrm{m}^{3}$ and $4190 \mathrm{EU} / \mathrm{m}^{3}$ more than in insulated cowsheds. Comparative analysis of endotoxin concentrations in different livestock houses indicated that in cowsheds, especially in the uninsulated ones, the contamination with endotoxins is smaller than in other livestock houses.

The analyses performed in order to clarify the bacteriological contamination in different livestock houses and identify the relationships between different values indicated that 
contamination with bacteria and endotoxins differed in livestock houses under study. It should be noted that in all air samples viable gram-negative bacteria were detected that might be a potential source of endotoxins. In the tests, correlation between the average amount of bacteria and endotoxins as well as between gram-negative bacteria and endotoxins concentrations were established in $1 \mathrm{~m}^{3}$ air.

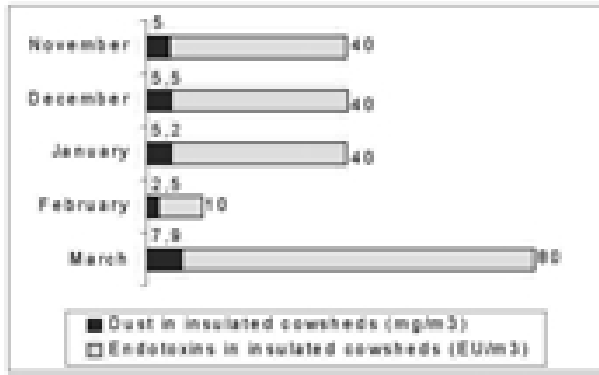

Fig. 1. Concentrations of dust and endotoxins in insulated cowsheds

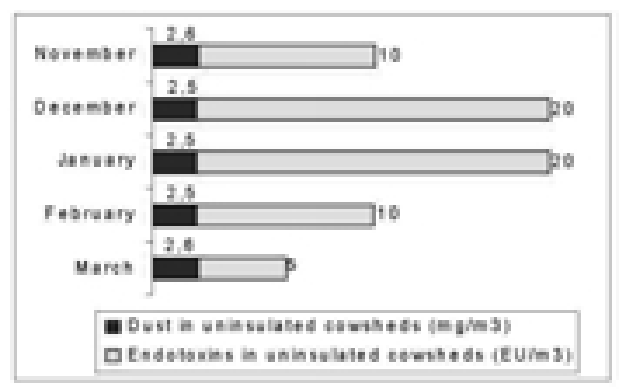

Fig. 2. Concentrations of dust and endotoxins in uninsulated cowsheds

In insulated cowsheds high positive correlation $(r=0.82)$ between average amount of bacteria and concentration of endotoxins was identified. This revealed that concentration of endotoxins increased with increasing general bacterial contamination. Amounts of gram-negative bacteria and endotoxins showed a medium positive correlation $(r=0.41)$. In pig houses, the average amount of bacteria and endotoxins as well as gram-negative bacteria and endotoxins showed high positive correlation $(r=0.78$ and $r=0.76$, respectively). Concentration of endotoxins increased with increasing bacterial contamination. High positive correlation $(r=0.64)$ between average amount of bacteria and concentration of airborne endotoxins was identified in the poultry houses. Medium positive correlation was observed between gram-negative bacteria and concentration of endotoxins in poultry houses $(r=0.59)$. No significant differences were found between several indices; therefore more detailed analyses are required.

Some authors affirm that airborne gram-negative bacteria survive in the environment for a short time; however, the endotoxins survive even after the death of bacteria (Müller et al. 1987). Referring to this fact, we tried to identify the relationship between airborne dust and concentration of endotoxins.

The research results reflecting dynamics of dust and endotoxins in the houses of different livestock are presented in Figs 1, 2, 3, and 4.

Measuring the pollution in cowsheds indicated that in insulated cowsheds dust concentrations ranged in the limits of $2.5-7.9 \mathrm{mg} / \mathrm{m}^{3}$ (average $5.2 \pm 0.87$ ). In uninsulated cowsheds concentrations of dust ranged between $2.5-2.6 \mathrm{mg} / \mathrm{m}^{3}$ (average $2.5 \pm 0.02 \mathrm{mg} / \mathrm{m}^{3}$ ). Much higher concentrations were determined in the pig houses compared to both insulated and uninsulated cowsheds. In the pig houses, concentrations of dust ranged between 5.4-8.2 $\mathrm{mg} / \mathrm{m} 3$ (average $7.1 \pm 0.66$ ). The analyses of dust pollution in poultry houses showed that concentrations of dust in the air ranged between $8.2-13.6 \mathrm{mg} / \mathrm{m}^{3}$ (average $11.4 \pm 1.01$ ). In all cases the differences were statistically significant $(p<0.001)$.

Correlation analysis revealed that correlation between the concentration of endotoxins and the amount of dust in insulated cowsheds was high, in uninsulated cowsheds - medium and in poultry-houses - low. Very high positive correlation $(r=0.98)$, detected between bacterial endotoxins and dust in insulated cowsheds showed that the amount of endotoxins in the air increases with increasing amount of dust in the livestock houses. High positive correlation $(r=0.64)$ between studied parameters was determined in pig houses, and in the poultry houses no correlation between these rates was observed $(r=0.02)$. 


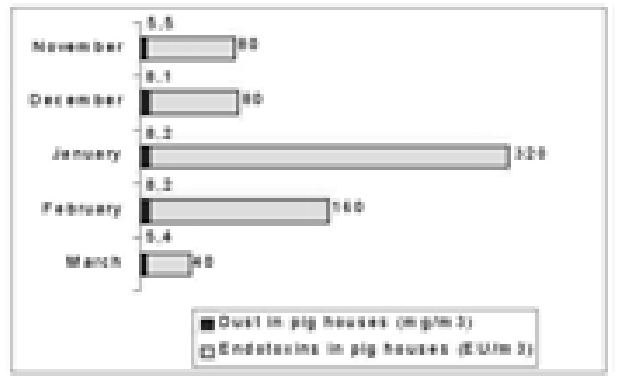

Fig. 3. Concentrations of dust and endotoxins in pig houses

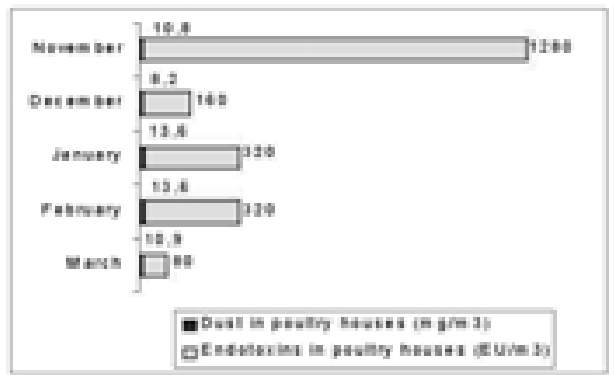

Fig. 4. Concentrations of dust and endotoxins in poultry houses

Past investigations showed the correlation between the total amount of bacteria and endotoxins and correlation between the gram-negative bacteria and endotoxins (Hartung and Seed orf 1999). Endotoxins are part of the outer membrane of Gram-negative bacteria and are present ubiquitously in the environment. The lipopolysaccharide (LPS) part of the molecule is responsible for its toxic properties. Environmental monitoring is usually performed by sampling airborne dust (Heederik and Douwes 1997).

Some authors affirm that airborne gram-negative bacteria survive in the environment for short time, but endotoxins do survive even after the death of bacteria (Müller et al. 1987). Referring to this fact, we tried to identify the relationship between airborne dust and concentration of endotoxins.

Our results showed that in cowsheds the concentrations of airborne bacteria were much lower than in pig houses and poultry houses, and, accordingly, the air contamination with dust and endotoxins was similar.

Positive correlation between the occurrence of bacterial endotoxins and dust in the air shows that higher amount of dust determines higher concentrations of endotoxins. The same correlation was found between general bacterial contamination in air and endotoxins. The amount of bacteria is usually higher during handling of grain, hay and bedding material; and exposure to endotoxins is higher during chopping of bedding material out and in animal houses except for possibly in cowsheds (Wijnand 1997).

There have been no studies done in Lithuania reporting contamination of air with airborne bacteria, endotoxins and dust in livestock and poultry houses. Their amount in air is different and they present a risk for both human and animal health. Moreover, these substances are evoporating from animal houses to the environment and cause environmental pollution with bio-aerosols. Urgent actions are required to investigate the travel distance of bioaerosols and whether and how particulate emissions from animal farming can cause health effects in residents living in the rural environment. The present work was undertaken to evaluate livestock houses and poultry houses in this respect. For licensing new animal farms as well as residential areas in the farming environment more precise information on the travel distance of harmful particles and compounds needs to be collected.

\section{Bakteriální kontaminace vzduchu ve stájích pro hospodářská zvířata a v drůbežárnách}

Vzduch ve stájích hospodářských zvířat obsahuje prach spolu s různým množstvím mikroorganismů. Mezi množstvím prachu a počtem mikroorganismů ve vzduchu existuje vztah. Cílem této studie bylo porovnat kvantitativní analýzy vzdušných bakterií, endotoxinů a prachu ve stájích hospodářských zvírat a v drůbežárnách. Ve vytápěných stájích pro dojnice bylo průměrné množství mikroorganismů a gram-negativních bakterií vyšší než ve 
stájích nevytápěných $(p<0.01)$. Ve vepřínech a v drůbežárnách bylo průměrné množství mikroorganismů a gram-negativních bakterií vyšší než ve vytápěných i nevytápěných stájích pro dojnice $(p<0.001)$ a vzduch $v$ těchto zařízeních byl oproti nim též více kontaminován endotoxiny $(p<0.01)$. Množství prachu bylo ve vytápěných stájích pro dojnice vyšší než v nevytápěných $(p<0.01)$. Ve vepřínech a drůbežárnách pak bylo množství prachu vyšší než obou druhů stájí $(p<0.001)$. Lze konstatovat, že mezi množstvím prachu, vzdušných bakterií a endotoxinů ve vzduchu stájí hospodářských zvířat a drůbežáren existuje úzký vztah. Data o kontaminaci vzduchu jsou potřebná pro schvalování staveb pro zvířata i pro rezidenční oblasti.

\section{References}

AFANASYEVA, G 1997: Opriedielenyje bakterialnich endotoksins kak alternativnij metod. Baltic J Lab Animal Sci 7: $187-199$

HARTUNG, J, SEEDORF, J 1999: Characterization of airborne dust in livestock housing and its effects on animal and environment. Intern. Symposium on dust control in animal production facilities. Congress Proceedings. Scandinavian Congress Center. Aarhus 30. 05-2.06: 140-152

HEEDERIK, D, DOUWES, J 1997: Towards an occupational exposure limit for endotoxins? Ann Agric Environ Med 4: 17-19

MÜLLER, W, WIESER, P 1987: Dust and microbial emissions from animal production. Strauch D (Hrsg.). Animal production and environmental health. Elsevier, Amsterdam-Oxford- New York-Tokio, pp. 47-89

NOWAK, D 1998: Die Wirkung von Stalluftbestandteilen, insbesondere in Schweineställen, aus arbeitsmedizinischer Sicht. Dtsch tierärztl Wschr 105: 225-234

RIETSCHEL, ET, BRADE, L, SCHADE, FU, SEYDEL, U, ZAHRINGER, U, MAMAT, U, SCHMIDT, G, ULMER, AJ, LOPPNOW, H, FLAD, HD, PADOVA, F, SCREIER, MH, BRADE, H 1993: Bakterielle Endotoxine: Beziehungen zwischen chemischer Konstitution und biologischer Wirkung. Immun Infekt 21: 26-35

PEARSON, F C, WEARY, M, BOHON, J 1982: Detection of Limulus Amebocyte Reactive Material in Capillary Flow Hemodialyzers. In: S. W. Watson and J. Levin (Ed.): Endotoxins and their Detection with the Limulus Amebocyte Lysate Test, Alan R. Liss, Inc., New York, pp. 247-260

RYLANDER, R 1987: The role of endotoxin for reactions after exposure to cotton dust. Am J Ind Med 12: 687-697

SITNIKOV, VAG, TRAVINA, LA, BAGIROVA, VL 1997: LAL test. Sovriemienije podxodi k opriedieleniju pirogennosti. Moskva, p. 96

WIJNAND, E 1997: Exposure to non-infectious microorganisms and endotoxins in agriculture. Ann Agric Environ Med 4: 179-186

TARVYDAS, A 1992: Zoohigienos praktikumas. Vilnius „Mokslas“, 145 p.

ZUCKER, BA, TROJAN, S, MÜLLER, W 2000a: Airborne gram-negative bacterial flora in animal houses. J Vet Med B 47: 37-46

ZUCKER, BA, DRAZ, AM, MÜLLER, W 2000b: Comparison of filtration and impingement for sampling airborne endotoxin. J Aerosol Sci 31: 751-755

ZUCKER, BA, MÜLLER, W 2000: Species composition and sources of airborne gram-negative bacteria in animal houses. $X^{\text {th }}$ International Congress on Animal Hygiene Maastricht. Vol I, pp. 393-397 